\title{
Selected Problems of Cultural Participation in Early and Late Adulthood
}

\begin{abstract}
The objective of this article is to describe surveys carried out in Poland which facilitated a comparison of selected forms of cultural activity and ways of cultural participation by people in their early and late adulthood, as well as its conditions and associated opinions. The analysis demonstrated that the model of cultural participation changes with age, which is a factor strongly differentiating between the mentioned fields of research. The majority of young people prefer mediated cultural participation, in which the Internet plays a significant role. Seniors prefer direct and elite forms of cultural activity. The respondents also differ in the way they assess the attractiveness of the forms of direct contact with culture. Most young people find popular music concerts and film screenings attractive, while seniors tend to go to classical music concerts, operettas and theatre performances. Adults also differ in respect of their opinions on the benefits of cultural participation and the majority of the associated barriers.
\end{abstract}

\section{Keywords:}

cultural participation and the age of adult people, manner of cultural participation, forms of cultural activity, conditions for cultural participation, opinions on cultural participation

\section{INTRODUCTION}

Over recent years, the discussion on cultural participation has become particularly animated in Europe (Tomka, 2013, p. 259). In Poland, the need for a new, recon-

Institute of Music Pedagogy, Faculty of Pedagogy and Psychology, Kazimierz Wielki University, Poland, E-MAIL: b.bonna@ukw.edu.pl. 
structed way of interpreting cultural participation has been brought up, among others, by M. Krajewski, who described it as "a process of including a given element, individual or group, but also an object, into a culturally regulated situation, which, therefore, takes place through language, standards and values, and the developed tools and items" (Krajewski, 2014, p. 15). In this broad sense, cultural participation does not entail only participating in cultural life, but in every situation in which an individual becomes a participant in relations that create a given community, and are responsible for its duration and reconstruction over time (Krajewski, 2014, p. 15).

It is worth noting the clear difference between the broad and narrow definition of cultural participation. The latter, nowadays criticised, is understood as "participation in artistic culture which is a subject of institutional popularisation activity” (Grad, 1997, p. 5). This phenomenon is regarded as corresponding to the passive consumption of cultural goods created by professional artists and institutions dealing with the popularisation of culture (Janicka-Olejnik, 2016, p. 58). The broad expression of cultural participation does not mean eliminating the threads connected with elite culture, which are still present in contemporary exploration, but enriched with new forms and institutions of culture, or its new media (Szlendak, 2014a, p. 29). Such an approach can also be seen in European studies (cf. O’Hagan, 2016, pp. 291-301).

Nowadays, cultural activity includes a greater spectrum of forms than it did in the past, and is closely related to the broad perception of cultural participation. Extending the range of these forms is the result of a contemporary, anthropological understanding of culture. New forms of cultural activity can, therefore, be examined within a continuum including the model of elite culture, which requires extensive involvement, competence and investment, the model of popular culture, which is easily understandable thanks to the accessibility of its content and simplicity, and the model of culture relating to the natural environment of people (Szlendak \& Olechnicki, 2014, pp. 295, 297-298; Janicka-Olejnik, 2016, p. 59).

On the other hand, in numerous studies, including those which treat participation very broadly, one would be hard-pressed to find an in-depth quantitative analysis which would warrant an inference on, and illustrate, the actual differences resulting from the adopted variables (e.g., age and education), as well as the common characteristics of the surveyed participants in culture. Therefore, it appears important to fill in the existing gaps in the analysis of the research material, and to take into account the changing attitude to cultural participation. The presented research takes into consideration the selected elements of the evolving understanding of cultural participation, with its author being aware of the selec- 
tiveness of the presented issues in the context of the promoted broad definition of cultural participation. It is, however, taken up consciously due to its unwavering timeliness. The research includes strands related to popular and elite culture. The classic, institutional, and direct forms of cultural activity were taken into account, as well as selected non-institutional practices and new practices until recently regarded as “non-cultural” or “entertainment” (cf. Szlendak, 2014b, pp. 147-192).

\section{THE METHODOLOGICAL CONTEXT OF THE RESEARCH}

The objective of the conducted research was to diagnose the selected forms of cultural activity and ways of cultural participation by people in their early and late adulthood, as well as its conditions and associated opinions.

In the course of research, the following problems were formulated related to the search for answers to the following research questions:

1. Does, and to what extent, the age of respondents differentiate between the manner of cultural participation and forms of cultural activity?

2. Does, and to what extent, the age of respondents differentiate between the opinions on cultural participation?

3. Does, and to what extent, the age of respondents differentiate between the conditions for cultural participation?

The research conducted in 2014-2016² was based on the diagnostic survey method, using the questionnaire technique. Data were obtained from 207 respondents from Kujawsko-Pomorskie, Pomorskie and Wielkopolskie Provinces. The surveyed community was composed of individuals in their early ${ }^{3}(\mathrm{~N}=100)$ and late $^{4}(\mathrm{~N}=107)$ adulthood. A chi-squared test was used to evaluate the significance of differences in frequency distribution between the groups. The selection of groups with generational differences was associated with the intention to capture and illustrate a model of cultural participation which changes with age.

2 The surveys were conducted by N. Papierz, K. Czapiewska, and A. Augustynowicz within a diploma seminar under the tutelage of the author of this study, who was also involved in the process.

The surveyed group included persons aged 20-35.

4 In the literature on the subject, there are considerable differences in defining late adulthood. For the purposes of this study, it was deemed that it starts at the age of 60 (cf. Straś-Romanowska, 2009, pp. 264-265). 


\section{DISCUSSION OF RESEARCH FINDINGS}

\section{SELECTED FORMS OF ACTIVITY AND MANNERS OF CULTURAL PARTICIPATION VS. THE AGE OF THE ADULT PEOPLE}

Various forms of cultural activity associated with receiving culture, understood traditionally, are taken up by $86 \%$ of older respondents and $79.44 \%$ of young adults, while, in addition, $14 \%$ of individuals from the first group and $20.56 \%$ of those in the second group were involved in cultural creation as amateurs. The analysis did not reveal any statistical differences between the respondents in this regard $\left(\mathrm{x}^{2}=2.171 \mathrm{px}^{2}=0.337\right)$. The respondents from both groups take up activities connected with singing in a choir or a vocal band, they paint, sculpt, write poetry, and take artistic photographs.

From the adopted research perspective, it appeared useful to obtain information on the preferred manner of cultural participation determining the involvement in specific forms of cultural activity.

Table 1. The preferred manner of cultural participation

\begin{tabular}{|c|c|c|c|c|}
\hline \multirow[t]{2}{*}{ Manner } & \multicolumn{2}{|c|}{$\begin{array}{l}\text { Early adulthood } \\
\qquad N=104^{*}\end{array}$} & \multicolumn{2}{|c|}{$\begin{array}{l}\text { Late adulthood } \\
\qquad N=97\end{array}$} \\
\hline & $\mathrm{N}$ & $\%$ & $\mathrm{~N}$ & $\%$ \\
\hline direct & 36 & 34.61 & 53 & 54.64 \\
\hline via the internet & 49 & 47.12 & 10 & 10.31 \\
\hline via the radio & 5 & 4.81 & 14 & 14.43 \\
\hline via television & 14 & 13.46 & 20 & 20.62 \\
\hline \multicolumn{5}{|c|}{$x^{2}=34.146 p x^{2}<0.001$} \\
\hline
\end{tabular}

The smaller number of respondents results from the fact that not all persons gave answers; $x^{2}$ - chi-squared; $p x^{2}$ - probability resulting from the conducted chi-squared test; $p \leq 0.05$ - significant difference; $p \leq 0.01$ - highly significant difference

It was demonstrated that more than half of the seniors opted for direct contact with culture. Younger respondents preferred to participate in culture via the Internet, in respect of which the highest percentage difference between the groups was recorded (38.81\%). The traditional media play a smaller role in both these communities. Nevertheless, this way of interacting with culture was somewhat favoured by the seniors. The surveys demonstrated statistical differences between respondents in the analysed field. According to the data published by Statistics Poland from 2014, nearly half of the respondents indicated that television and the Internet could not replace direct cultural participation, especially going to concerts and exhibitions, theatres and museums, which confirms the high attractiveness of participation in cultural events (cf. Radkowski et al., 2016, pp. 77, 81). 
The justifications proposed by representatives of both analysed groups included statements which displayed values stemming from experiencing culture directly, and its emotional nature. "Direct cultural participation releases more energy, emotions and experiences”; “It deeply moves your soul”; "It gives me vigour”. There were also voices pointing to the social dimension of a close relationship with culture: "Thanks to such a form of cultural activity, you can get to know many interesting people”. The limitations and advantages resulting from mediated cultural participation were also noticed. "The media make it impossible to become more involved in a given form of culture and its reception"; "Contact with culture via the Internet is more accessible, as you can watch a film, a concert or something else at any given moment". One should presume that the preferences connected with the manner of cultural participation result from generational differences between the respondents. Young people find it exceptionally easy to surf the Internet, searching within the plethora of suggestions for the films, concerts and information which interest them, and share these with other people (cf. Filiciak et al., 2010, pp. 53-60). Older people often have problems with that, which might be the reason why they more often seek the aforementioned full involvement in direct contact with culture, which triggers strong emotions and which is otherwise hard to attain.

The attractiveness of forms of activity related to direct cultural participation was also evaluated.

Table 2. The attractiveness of cultural activity in direct contact with culture

\begin{tabular}{|l|c|c|c|c|c|c|}
\hline \multirow{2}{*}{ Form } & \multicolumn{2}{|c|}{$\begin{array}{c}\text { Early adulthood } \\
\mathrm{N}=107\end{array}$} & \multicolumn{2}{c|}{$\begin{array}{c}\text { Late adulthood } \\
\mathrm{N}=100\end{array}$} & \multicolumn{2}{c|}{ Statistics } \\
\cline { 2 - 7 } & $\mathrm{N}$ & $\%$ & $\mathrm{~N}$ & $\%$ & $\chi^{2}$ & $\mathrm{px^{2 }}$ \\
\hline classical music concert & 11 & 10.28 & 33 & 33.00 & 15.941 & $<0.001$ \\
\hline opera & 6 & 5.61 & 25 & 25.00 & 15.266 & $<0.001$ \\
\hline operetta & 4 & 3.74 & 33 & 33.00 & 30.151 & $<0.001$ \\
\hline ballet & 9 & 8.41 & 8 & 8.00 & 0.011 & 0.914 \\
\hline popular music concert & 60 & 56.07 & 25 & 25.00 & 20.624 & $<0.001$ \\
\hline theatre performance & 21 & 19.63 & 32 & 32.00 & 4.154 & $<0.05$ \\
\hline film screening & 72 & 67.29 & 16 & 16.00 & 55.639 & $<0.001$ \\
\hline museum exhibition & 5 & 4.67 & 10 & 10.00 & 2.182 & 0.139 \\
\hline vernissage & 5 & 4.67 & 2 & 2.00 & 1.130 & 0.287 \\
\hline sketch comedy & 29 & 27.10 & 6 & 6.00 & 16.384 & $<0.001$ \\
\hline fair & 17 & 15.89 & 2 & 2.00 & 11.959 & $<0.001$ \\
\hline
\end{tabular}

The analysis demonstrated statistical differences between the groups, which means that they differ in terms of their opinion on the attractiveness of most forms 
of cultural activity. The results were diversified the most (51.29\%) in respect of film screenings, which in the group of younger respondents ranked first, while films enjoyed only $16 \%$ support among the representatives of late adulthood. Another statistical difference refers to popular music concerts, which were found attractive by $31.07 \%$ more of the representatives of this group. On the other hand, operettas (a $29.26 \%$ difference), classical music concerts (a 22.72\% difference) and operas (a 19.39\% difference) turned out to be more attractive for the seniors. In the group of young adults, apart from film screenings, the strongest support was recorded for popular music concerts and sketch comedy, while the weakest interest was in respect of operettas, operas, museum exhibitions and vernissages.

Seniors found classical music concerts and operettas the most attractive. These were followed by theatre performances, operas and popular music concerts. Fairs and vernissages, and also sketch comedy, proved the least popular among them. When discussing the obtained results, it is worth taking note of the respondents' tastes in music. Surveys and common observations indicate that young people tend to prefer popular music and are open to various musical styles. This openness disappears among the older population, which perhaps explains their preference for art music (cf. LeBlanc 1991, pp. 66-73; LeBlanc et al., 1996, pp. 49-59). Furthermore, musical education, formerly thought out for a longer time and covering more extensive content, could have contributed to the recognition of the value of and to stimulating interest in art music, whose familiarity was considered a compulsory part of education (cf. Bonna, 2014, pp. 211-226).

In order to particularise information on the preferred manner of cultural participation, the analysis includes the place and form of activities taken up by the respondents.

Table 3. Listening to classical music

\begin{tabular}{|l|c|c|c|c|c|c|}
\hline \multirow{2}{*}{$\begin{array}{c}\text { Place/the media/ } \\
\text { medium }\end{array}$} & \multicolumn{2}{|c|}{$\begin{array}{c}\text { Early adulthood } \\
\mathrm{N}=107\end{array}$} & \multicolumn{2}{c|}{$\begin{array}{c}\text { Late adulthood } \\
\mathrm{N}=100\end{array}$} & \multicolumn{2}{c|}{ Statistics } \\
\cline { 2 - 7 } & $\mathrm{N}$ & $\%$ & $\mathrm{~N}$ & $\%$ & $\chi^{2}$ & $\mathrm{p} \times 2$ \\
\hline philharmonic & 14 & 13.08 & 53 & 53.00 & 37.622 & $<0.001$ \\
\hline opera & 15 & 14.02 & 30 & 30.00 & 7.759 & $<0.01$ \\
\hline community centre & 2 & 1.87 & 3 & 3.00 & 0.280 & 0.596 \\
\hline open air & 1 & 0.93 & 1 & 1.00 & 0.002 & 0.961 \\
\hline radio & 21 & 19.63 & 43 & 43.00 & 13.222 & $<0.001$ \\
\hline television & 11 & 10.28 & 27 & 27.00 & 9.641 & $<0.01$ \\
\hline the internet & 29 & 27.10 & 4 & 4.00 & 20.588 & $<0.001$ \\
\hline records & 16 & 14.95 & 33 & 33.00 & 9.317 & $<0.01$ \\
\hline
\end{tabular}


Again, the membership of a given group differentiated statistically between nearly all the responses connected with listening to classical music. Only community centres and open air received a similar small number of votes. More than half of the representatives of late adulthood listen to classical music in philharmonics, and a third also in operas. When it came to the media, the radio was the most popular, with the Internet being the least popular, which, however, garnered the most votes $(27.10 \%)$ in the other group. It was also determined that the largest percentage difference between the groups concerned philharmonics (39.92\%), the radio (23.37\%), and the Internet (23.10\%). One can, therefore, infer that the seniors prefer institutional contact with art music or via the traditional media, while the younger individuals listen to classical music mainly in the media, also the new media, which is in line with the previous declarations of the respondents.

Responses concerning favourite classical music composers also point to a statistical difference between the groups $\left(x^{2}=11.402 \mathrm{px}^{2}<0.001\right)$. The analysis revealed that $40 \%$ of the older and only $18.69 \%$ of the younger adults acknowledged having such favourite composers, which again confirms a greater interest in art music among the seniors; however, in both communities the best-known artists were cited the most often - F. Chopin, J.S. Bach, W.A. Mozart, and L. van Beethoven.

The surveys also demonstrated statistical differences between the surveyed individuals' responses related to the reception of popular music.

Table 4. Listening to popular music

\begin{tabular}{|l|c|c|c|c|c|c|}
\hline \multirow{2}{*}{$\begin{array}{c}\text { Place/the media/ } \\
\text { medium }\end{array}$} & \multicolumn{2}{|c|}{$\begin{array}{c}\text { Early adulthood } \\
\mathrm{N}=107\end{array}$} & \multicolumn{2}{c|}{$\begin{array}{c}\text { Late adulthood } \\
\mathrm{N}=100\end{array}$} & \multicolumn{2}{c|}{ Statistics } \\
\cline { 2 - 7 } & $\mathrm{N}$ & $\%$ & $\mathrm{~N}$ & $\%$ & $\chi^{2}$ & $\mathrm{px}^{2}$ \\
\hline philharmonic & 1 & 0.93 & 21 & 21.00 & 21.910 & $<0.001$ \\
\hline community centre & 1 & 0.93 & 6 & 6.00 & 4.059 & $<0.05$ \\
\hline club & 55 & 51.40 & 1 & 1.00 & 66.539 & $<0.001$ \\
\hline open air & 29 & 27.10 & 2 & 2.00 & 25.561 & $<0.001$ \\
\hline radio & 76 & 71.03 & 78 & 78.00 & 1.319 & 0.250 \\
\hline television & 55 & 51.40 & 46 & 46.00 & 0.603 & 0.437 \\
\hline the internet & 78 & 72.90 & 20 & 20.00 & 58.018 & $<0.001$ \\
\hline records & 42 & 39.25 & 22 & 22.00 & 7.203 & $<0.01$ \\
\hline
\end{tabular}

Only radio and television garnered similar numbers of votes in both groups. Among young adults yet again the Internet and other media were the most popular. Clubs were characterised by the same number of responses as television, and more 
than half of the respondents listened to popular music in them. Nearly $40 \%$ of young adults listen to popular music on records. Only one respondent in this group went to a philharmonic or a community centre to listen to popular music. On the other hand, most seniors preferred contact with popular music via the media, with the traditional ones - radio and television - being the most popular. The highest percentage difference between the groups again concerned the Internet (52.90\%) and clubs (50.40\%), which, perhaps unsurprisingly, were frequented by only one representative of late adulthood.

More than half of the young (52.34\%) and older (54\%) adults had their favourite popular music bands and singers $\left(X^{2}=0.057 \mathrm{pX}^{2}=0.810\right)$. The representatives of late adulthood listed, among others, I. Santor, A.M. Jopek, A. German, K. Krawczyk, and Budka Suflera, while the younger individuals pointed to K. Nosowska, Rihanna, Shakira, E. Górniak and such bands as Kult, Hey, and Coma. It is worth noting that older individuals mainly liked artists they had known during their time of youth, which confirms the opinion that preferences from this time remain for many years (Pałosz, 2009, p. 167).

Further analysis demonstrated statistical differences between membership of a given group and responses as regards television, theatres and community centres in which the respondents could watch theatrical performances.

Table 5. Watching theatre performances

\begin{tabular}{|l|c|c|c|c|c|c|}
\hline \multirow{2}{*}{ Place/the media } & \multicolumn{2}{|c|}{$\begin{array}{c}\text { Early adulthood } \\
\mathrm{N}=107\end{array}$} & \multicolumn{2}{c|}{$\begin{array}{c}\text { Late adulthood } \\
\mathrm{N}=100\end{array}$} & \multicolumn{2}{c|}{ Statistics } \\
\cline { 2 - 7 } & $\mathrm{N}$ & $\%$ & $\mathrm{~N}$ & $\%$ & $\mathrm{X}^{2}$ & $\mathrm{PX}^{2}$ \\
\hline theatre & 60 & 56.07 & 75 & 75.00 & 8.161 & $<0.01$ \\
\hline community centre & 10 & 9.35 & 2 & 2.00 & 5.107 & $<0.05$ \\
\hline television & 28 & 26.17 & 53 & 53.00 & 15.624 & $<0.001$ \\
\hline the internet & 5 & 4.67 & 3 & 3.00 & 0.389 & 0.532 \\
\hline
\end{tabular}

The results revealed that $3 / 4$ of the seniors went to the theatre, with theatrical performances being watched on television by more than half of the respondents. In the other group, fewer individuals were recorded in both cases, with the theatre also being the most popular medium. According to the data, community centres did not enjoy much popularity in either of these generations, and only a few people watched theatre performances on the Internet.

Collecting information on the place and manner in which the respondents watch films also appeared interesting. 
Table 6. Watching films

\begin{tabular}{|l|c|c|c|c|c|c|}
\hline \multirow{2}{*}{$\begin{array}{c}\text { Place/the media/ } \\
\text { medium }\end{array}$} & \multicolumn{2}{c|}{$\begin{array}{c}\text { Early adulthood } \\
\mathrm{N}=107\end{array}$} & \multicolumn{2}{c|}{$\begin{array}{c}\text { Late adulthood } \\
\mathrm{N}=100\end{array}$} & \multicolumn{2}{c|}{ Statistics } \\
\cline { 2 - 7 } & $\mathrm{N}$ & $\%$ & $\mathrm{~N}$ & $\%$ & $\chi^{2}$ & $\mathrm{PX}^{2}$ \\
\hline cinema & 78 & 72.90 & 48 & 48.00 & 13.452 & $<0.001$ \\
\hline television & 80 & 74.77 & 88 & 88.00 & 5.920 & $<0.05$ \\
\hline the internet & 77 & 71.96 & 9 & 9.00 & 84.379 & $<0.001$ \\
\hline DVDs & 12 & 11.21 & 0 & 0.00 & 11.905 & $<0.001$ \\
\hline
\end{tabular}

Statistical differences between the groups were recorded in all terms. In both these communities, most people watched films on television. Cinema also turned out very popular among young adults. Seniors did not visit these cultural institutions that often, also among them there were not many enthusiasts of watching films on the Internet, which is used by $62.96 \%$ more young respondents.

Another step in this research was to collect information on activities related to viewing art exhibitions.

Table 7. Viewing art exhibitions

\begin{tabular}{|l|c|c|c|c|c|c|}
\hline \multirow{2}{*}{ Place/the media } & \multicolumn{2}{|c|}{$\begin{array}{c}\text { Early adulthood } \\
\mathrm{N}=107\end{array}$} & \multicolumn{2}{c|}{$\begin{array}{c}\text { Late adulthood } \\
\mathrm{N}=100\end{array}$} & \multicolumn{2}{c|}{ Statistics } \\
\cline { 2 - 7 } & $\mathrm{N}$ & $\%$ & $\mathrm{~N}$ & $\%$ & $\mathrm{X}^{2}$ & $\mathrm{PX}^{2}$ \\
\hline art gallery & 16 & 14.95 & 33 & 33.00 & 9.317 & $<0.01$ \\
\hline museum & 20 & 18.69 & 47 & 47.00 & 18.922 & $<0.001$ \\
\hline community centre & 13 & 12.15 & 7 & 7.00 & 1.570 & 0.210 \\
\hline library & 19 & 17.76 & 20 & 20.00 & 0.170 & 0.680 \\
\hline open air & 20 & 18.69 & 4 & 4.00 & 10.885 & $<0.001$ \\
\hline shopping centre & 25 & 23.36 & 10 & 10.00 & 6.571 & $<0.05$ \\
\hline television & 4 & 3.74 & 22 & 22.00 & 15.695 & $<0.001$ \\
\hline
\end{tabular}

The data show that only indications concerning places such as libraries and community centres did not differentiate between the respondents' answers, while statistical differences were found in other cases. Most young adults attend art exhibitions in shopping centres, which demonstrates the changing manner of cultural participation. Open air, museums, libraries and art galleries proved slightly less popular. Watching TV programmes devoted to art and architecture attracted the least interest. Senior individuals appear to prefer traditional forms of cultural activity. Most people go to museums and art galleries, and every fifth respondent views art exhibitions in libraries. 
Reading is an important form of cultural activity. As evidenced by surveys, $8.60 \%$ of young adults and $10.10 \%$ of the representatives of late adulthood read one book in a 6 -month period. Several books were read by $66.67 \%$ of the younger and $73.74 \%$ of the older individuals. $24.73 \%$ of individuals in the early adulthood group and $16.16 \%$ of the representatives of late adulthood did not read any books. The analysis did not reveal any statistical differences between the groups $\left(x^{2}=2.189 \mathrm{px}^{2}=0.334\right)$.

The surveyed individuals obtained books in a number of different ways. The data inform us that only listening to audiobooks, practised by a few people, did not differentiate between the surveyed groups.

\section{Table 8. The manner of obtaining books}

\begin{tabular}{|c|c|c|c|c|c|c|}
\hline \multirow[t]{2}{*}{ Manner } & \multicolumn{2}{|c|}{$\begin{array}{l}\text { Early adulthood } \\
\qquad N=107\end{array}$} & \multicolumn{2}{|c|}{$\begin{array}{l}\text { Late adulthood } \\
\qquad N=100\end{array}$} & \multicolumn{2}{|c|}{ Statistics } \\
\hline & $N$ & $\%$ & $N$ & $\%$ & $x^{2}$ & $\mathrm{px}^{2}$ \\
\hline borrowing & 57 & 53.27 & 87 & 87.00 & 27.775 & $<0.001$ \\
\hline buying & 64 & 59.81 & 34 & 34.00 & 13.815 & $<0.001$ \\
\hline downloading from the Internet & 23 & 21.50 & 3 & 3.00 & 16.100 & $<0.001$ \\
\hline using audiobooks & 2 & 1.87 & 4 & 2.00 & 0.833 & 0.361 \\
\hline
\end{tabular}

The analyses indicated that seniors preferred to borrow books, while young adults opted for buying as well as borrowing, in respect of which the highest percentage difference between the groups was recorded (33.73\%). It was also identified that one in four young adults used books published on the Internet, while in the other group the use of this medium again proved unpopular.

When discussing the obtained results, it is worth underlining that in relation to other surveys, this study demonstrated a lower percentage of seniors dealing with amateur cultural creation (cf. Landsberg et al., 2012, p. 52) and a higher share of people undertaking cultural activity connected with going to philharmonics, opera, theatrical performances, to the museum or art gallery (cf. Radkowski et al., 2016, pp. 86-87; Szlendak, 2014b, pp. 154-160). Reading activity, especially by older respondents, also proved higher (cf. Koryś et al., 2017, pp. 11, 26). It was also noted that more people borrowed books, which can indicate a growing interest in this manner of obtaining them. It was confirmed that the presence of literature in a digital form is still a relatively rare sight in households, as well as that adults infrequently participate in cultural events organised by community centres. In the senior group, a lower interest in films on various media was observed, with an equally high interest in watching films on television, and a higher interest in going 
to the cinema. More young adults using the Internet were recorded, and, similarly to other surveys, a percentage of older individuals which decreased with age (cf. Landsberg et al., 2012, pp. 35, 48, 50). It was confirmed that the media played a significant role in the cultural activity of adults.

\section{SELECTED OPINIONS ON CULTURAL PARTICIPATION VS. THE AGE OF ADULT PEOPLE} In the next section of the survey, respondents were asked whether cultural participation was important to them. Positive responses were given by most members of both groups $-78 \%$ of the older and $64.15 \%$ of the younger adults. It was not important to a small percentage of representatives of late (7\%) and early (8.49\%) adulthood, whereas $15 \%$ of the older and $27.36 \%$ of the younger respondents could not clearly identify their attitude to the matter in question. The distribution of results was similar in both groups $\left(x^{2}=5.219 \mathrm{px}^{2}=0.073\right)$. Data published by Statistics Poland confirm that culture is important to most young (84\%) and older (77.3\%) Poles (cf. Radkowski et al., 2016, p. 55).

In their justifications, the respondents wrote "Cultural participation enriches my life and gives me an opportunity to reflect on it”; "Through cultural participation you can develop your interests and satisfy your individual needs”. The cited arguments corroborated the respondents' opinions on the benefits of cultural participation, which are presented below.

Table 9. Opinions on the benefits of cultural participation

\begin{tabular}{|l|c|c|c|c|c|c|}
\hline \multirow{2}{*}{\multicolumn{1}{|c|}{ Benefits }} & \multicolumn{2}{c|}{$\begin{array}{c}\text { Early adulthood } \\
\mathrm{N}=107\end{array}$} & $\begin{array}{c}\text { Late adulthood } \\
\mathrm{N}=100\end{array}$ & \multicolumn{2}{c|}{ Statistics } \\
\cline { 2 - 8 } & $\mathrm{N}$ & $\%$ & $\mathrm{~N}$ & $\%$ & $\mathrm{X}^{2}$ & $\mathrm{PX}^{2}$ \\
\hline gives a sense of fulfilment and happiness & 38 & 35.51 & 17 & 17.00 & 9.081 & $<0.01$ \\
\hline provides aesthetic experiences & 27 & 25.23 & 31 & 31.00 & 0.852 & 0.355 \\
\hline makes you richer inside & 49 & 45.79 & 43 & 43.00 & 0.163 & 0.685 \\
\hline makes you more sensitive & 39 & 36.45 & 29 & 29.00 & 1.300 & 0.254 \\
\hline $\begin{array}{l}\text { draws your attention to new phenomena } \\
\text { problems and situations }\end{array}$ & 26 & 24.30 & 16 & 16.00 & 2.201 & 0.137 \\
\hline provokes reflection & 49 & 45.79 & 27 & 27.00 & 7.858 & $<0.01$ \\
\hline fosters creative activity & 13 & 12.15 & 3 & 3.00 & 6.067 & $<0.05$ \\
\hline shapes the value system & 32 & 29.91 & 6 & 6.00 & 19.711 & $<0.001$ \\
\hline $\begin{array}{l}\text { broadens the knowledge of the world } \\
\text { around you }\end{array}$ & 27 & 25.23 & 28 & 28.00 & 0.202 & 0.652 \\
\hline is a form of entertainment & 49 & 45.79 & 22 & 22.00 & 12.986 & $<0.001$ \\
\hline
\end{tabular}




\begin{tabular}{|l|c|c|c|c|c|c|}
\hline \multicolumn{1}{|c|}{ Benefits } & \multicolumn{2}{c|}{$\begin{array}{c}\text { Early adulthood } \\
\mathrm{N}=107\end{array}$} & \multicolumn{2}{c|}{$\begin{array}{c}\text { Late adulthood } \\
\mathrm{N}=100\end{array}$} & \multicolumn{2}{c|}{ Statistics } \\
\cline { 2 - 8 } & $\mathrm{N}$ & $\%$ & $\mathrm{~N}$ & $\%$ & $\mathrm{X}^{2}$ & $\mathrm{px}^{2}$ \\
\hline is a spare time activity & 46 & 42.99 & 35 & 35.00 & 3.551 & 0.169 \\
\hline $\begin{array}{l}\text { gives you an opportunity to spend spare } \\
\text { time with friends }\end{array}$ & 27 & 25.23 & 9 & 9.00 & 10.622 & $<0.01$ \\
\hline $\begin{array}{l}\text { gives you an opportunity to spend spare } \\
\text { time with family }\end{array}$ & 15 & 14.02 & 2 & 2.00 & 9.905 & $<0.01$ \\
\hline
\end{tabular}

The surveyed individuals unanimously stated that cultural participation made people richer inside, provided aesthetic experiences, made you more sensitive, drew your attention to new phenomena and problems, broadened the knowledge of the world around you, and was a spare time activity. Therefore, culture seems to influence human beings without limiting them to passive reception, irrespective of the manner of participation. Both groups are different in statistical terms in their assessment of the benefits associated with shaping the value system, providing entertainment, provoking reflection, giving a sense of fulfilment and happiness, giving opportunities for spending spare time with friends and family, and fostering creative activity. It is worth noting that more young adults reported the listed benefits. The surveyed individuals showed deep, emotional, and aesthetic dimensions of the influence of culture, as well as its ludic functions.

Interestingly, more representatives of late (93.81\%) than early (74.26\%) adulthood could not imagine living without access to culture. Only $4.95 \%$ of the young respondents thought differently, within the rest of the respondents, both those younger (20.79\%) and older (6.19\%) found it difficult to give explicit answers. The surveys demonstrated a statistical difference between the groups in the analysed field $\left(\mathrm{X}^{2}=14.800 \mathrm{px}^{2}<0.001\right)$. The justification for this included such statements as "Culture surrounds us from all sides, there is no society without culture"; "Culture is ever-present in our lives, without it human existence would be pointless”. Cultural participation, therefore, forms an important part of the lives of the majority of the respondents. Similar emotionally loaded expressions which corroborate this fact can be found in a report on a survey of seniors' cultural activity (cf. Landsberg et al., 2012, pp. 34, 43-44).

No significant difference was found between age and the respondents' selfassessment of their cultural participation $\left(\chi^{2}=0.409 \mathrm{pX}^{2}=0.815\right)$, which was classified as high by only $6.06 \%$ of the older and $5.77 \%$ of the younger respondents. Most representatives of late (72.73\%) and early (69.23\%) adulthood considered it average, while $21.21 \%$ representatives of the older and 25\% of the younger generation regarded their cultural activity as low. 


\section{SELECTED CONDITIONS OF CULTURAL PARTICIPATION VS. THE AGE OF THE ADULT PEOPLE}

It appeared interesting to identify barriers which, in the respondents' opinion, could affect their cultural activity related to direct cultural participation.

Table 10. Barriers to direct cultural participation

\begin{tabular}{|c|c|c|c|c|c|}
\hline \multirow[t]{2}{*}{ Barriers } & \multirow[t]{2}{*}{ Responses } & \multicolumn{2}{|c|}{$\begin{array}{l}\text { Early adulthood } \\
\qquad N=107\end{array}$} & \multicolumn{2}{|c|}{$\begin{array}{l}\text { Late adulthood } \\
\qquad N=100\end{array}$} \\
\hline & & $\mathrm{N}$ & $\%$ & $\mathrm{~N}$ & $\%$ \\
\hline \multirow{2}{*}{ financial means } & Limit & 63 & 58.88 & 66 & 66.00 \\
\hline & Do not limit & 44 & 41.12 & 34 & 34.00 \\
\hline \multicolumn{6}{|c|}{$x^{2}=2.407 p x^{2}=0.300$} \\
\hline \multirow{2}{*}{ lack of time } & Limits & 68 & 63.55 & 26 & 26.00 \\
\hline & Does not limit & 39 & 36.45 & 74 & 74.00 \\
\hline \multicolumn{6}{|c|}{$x^{2}=29.403 p x^{2}<0.001$} \\
\hline \multirow{2}{*}{$\begin{array}{c}\text { distance to places hosting } \\
\text { cultural events }\end{array}$} & Limits & 37 & 34.58 & 19 & 19.00 \\
\hline & Does not limit & 70 & 65.42 & 81 & 81.00 \\
\hline \multicolumn{6}{|c|}{$x^{2}=6.357 p x^{2}<0.05$} \\
\hline \multirow{2}{*}{ lack of company } & Limits & 45 & 42.06 & 28 & 28.00 \\
\hline & Does not limit & 62 & 57.94 & 72 & 72.00 \\
\hline \multicolumn{6}{|c|}{$x^{2}=4.473 \mathrm{px}^{2}<0.05$} \\
\hline
\end{tabular}

Among younger individuals, it was the lack of time which proved the greatest barrier, which was not surprising, as their numerous professional and family obligations could effectively limit their cultural activities. This problem, however, did not apply to most seniors. The analyses displayed very high differences between the groups in this regard. In other surveys concerning the cultural activity of seniors, this factor also did not constitute a barrier for senior individuals (82.4\%) (cf. Landsberg et al., 2012, p. 58); however, it has ranked highly among other barriers in other surveys of the cultural practices of Poles, even though it involved only $21.9 \%$ of the population (cf. Szlendak, 2014b, p. 211).

Further analyses demonstrated that the respondents significantly differed in their assessment of other factors which conditioned their cultural activities, such as the lack of company or the distance to places hosting cultural events; however, these were barriers for a higher percentage of young adults. As evidenced by the data, the lack of the possibility of going to such places in the company of other people limited the activities of a significant proportion of the young people (42.06\%). This was less the case for the older adults (28\%). One can, therefore, 
conclude that more representatives of late adulthood accepted the fact of engaging in such activity on their own, which is confirmed by other surveys (cf. Landsberg et al., 2012, p. 58). Also, the distances to places hosting cultural events limited only $19 \%$ of such individuals and nearly twice as many representatives of the other group (34.58\%).

As one could presume, financial means effectively limit the direct cultural participation of more than half of the respondents, with the representatives of both groups showing agreement in this respect $\left(x^{2}=2.407 p x^{2}=0.300\right)$. They were also unanimous in evaluating the prices of tickets to cultural events, with the vast majority of older (76\%) and younger (71.70\%) respondents stating that they were too high. A small fraction of representatives of late (24\%) and early (27.37\%) adulthood regarded them as appropriate, and only one person $(0.93 \%)$ indicated that they were too low $\left(x^{2}=1.298 \mathrm{px}^{2}=0.522\right)$. In other surveys, financial means are also cited as a major barrier to cultural participation (cf. Landsberg et al., 2012, p. 58; Szlendak, 2014b, p. 211).

In addition to barriers limiting direct cultural participation, the analysed factors included those intensifying respondents' cultural activity.

Table 11. Factors intensifying cultural activity

\begin{tabular}{|l|c|c|c|c|c|c|}
\hline \multirow{2}{*}{\multicolumn{1}{|c}{ Factors }} & \multicolumn{2}{c|}{$\begin{array}{c}\text { Early adulthood } \\
\mathrm{N}=107\end{array}$} & \multicolumn{2}{c|}{$\begin{array}{c}\text { Late adulthood } \\
\mathrm{N}=100\end{array}$} & \multicolumn{2}{c|}{ Statistics } \\
\cline { 2 - 7 } & $\mathrm{N}$ & $\%$ & $\mathrm{~N}$ & $\%$ & $\mathrm{X}^{2}$ & $\mathrm{px}^{2}$ \\
\hline interests & 94 & 87.85 & 85 & 85.00 & 0.359 & 0.549 \\
\hline advertisements & 19 & 17.76 & 13 & 13.00 & 0.895 & 0.344 \\
\hline encouragement by family & 17 & 15.89 & 10 & 10.00 & 1.579 & 0.208 \\
\hline encouragement by friends & 59 & 55.14 & 21 & 21.00 & 25.409 & $<0.001$ \\
\hline
\end{tabular}

In both groups the distribution of results concerning three out of four specified factors was similar, with interests determining the activities of the highest percentage of the respondents (more than 80\%). Advertisements and encouragement by families had a much smaller impact. On the other hand, encouragement by friends, which is followed by $34.14 \%$ more representatives of early adulthood, was a factor which considerably differentiated between the two groups.

Without any doubt, cultural activities create many opportunities to establish and strengthen social relations, which, according to R. Drozdowski (2014, p. 267) “[...] appear [...] important and noteworthy, since they make [cultural practices] more probable, create/co-create, enable, and sometimes seem to «programme» [them] from start to finish [...]”. Joint participation in culture appears to favour 
developing the depth of social and family relations. It constitutes an excellent opportunity to exchange thoughts, reflections and share experiences. Therefore, it appeared interesting to determine who accompanies respondents to places hosting cultural events.

Table 12. Persons accompanying the respondents during cultural events

\begin{tabular}{|c|c|c|c|c|c|c|}
\hline \multirow{2}{*}{ Responses } & \multicolumn{2}{|c|}{$\begin{array}{l}\text { Early adulthood } \\
\qquad N=107\end{array}$} & \multicolumn{2}{|c|}{$\begin{array}{l}\text { Late adulthood } \\
\qquad N=100\end{array}$} & \multicolumn{2}{|c|}{ Statistics } \\
\hline & $\mathrm{N}$ & $\%$ & $\mathrm{~N}$ & $\%$ & $x^{2}$ & $p x^{2}$ \\
\hline spouse/partner & 31 & 28.97 & 20 & 20.00 & 2.240 & 0.134 \\
\hline other family members & 29 & 27.10 & 40 & 40.00 & 3.869 & $<0.05$ \\
\hline friend & 71 & 66.36 & 47 & 47.00 & 7.900 & $<0.01$ \\
\hline going alone & 19 & 17.76 & 33 & 33.00 & 6.384 & $<0.05$ \\
\hline
\end{tabular}

The analysis revealed statistical differences between membership in a given group and respondents' answers. A similar distribution of results was observed only in the case of spouses/partners with whom the respondents participated in culture. Cultural events were frequented in the company of friends by $19.36 \%$ more young adults. However, this type of company is preferred in both groups. On the other hand, 15.24\% more seniors participated in such events alone. Also, $12.9 \%$ more participated in cultural events together with family members, which confirmed previous findings.

\section{CONCLUSIONS}

The surveys demonstrated that the model of cultural participation changed with age, with this factor strongly differentiating between the forms of activity, the manner of the cultural participation of adults, and the related conditions and opinions. The vast majority of young adults preferred mediated contact with culture, with the main role in such forms of activity as listening to popular and classical music played by the Internet, which appeared to successfully compete with the traditional media. In contrast to the younger generation, the seniors preferred direct cultural participation. They were mostly classical music enthusiasts, traditionalists who listened to it in various cultural institutions, and participated, at the same time, in the elite forms of contact with art. Statistically, more representatives of late adulthood listened to classical music in philharmonics and opera houses, but also on the radio, television and records. On the other hand, younger people 
preferred popular culture, and were enthusiasts of popular music, also listening to it in clubs and at open-air events, as well as outside the Internet, using traditional media and records. Adults also differed in terms of their assessment of the attractiveness of other forms of cultural activity. More seniors regarded theatre performances as attractive, while young people more often cited film screenings, sketch comedy shows and festivals. The respondents also differed in respect of the places in which they watched theatre performances, films and art exhibitions, as well as in the manner of obtaining books.

For the majority of adults, cultural participation was important, but more seniors could not imagine living without access to culture. The respondents' selfassessment of their cultural participation did not differentiate between them, with the vast majority regarding it as average. Both younger and older respondents unanimously stated that the benefits resulting from cultural participation were connected, i.a., with the provision of aesthetic experiences, becoming richer inside, and spending free time. They do differ, however, in respect of evaluating other values associated, for example, with provoking reflection, shaping the value system and providing entertainment, with more young people finding these important.

Among the barriers to direct cultural participation, only financial means did not differentiate between the respondents, while the lack of company and time, and the distance to places hosting cultural events, constituted greater barriers for young adults. The respondents were concordant in their assessment of the factors which intensified their cultural activity, such as interests, advertisements and encouragement by family.

Surveys of adults' cultural participation can constitute an important source of information for planning cultural policy, especially as regards undertaking activities to increase cultural competence and minimising barriers to cultural participation.

\section{References}

Bonna, B. (2014). Muzyka i edukacja muzyczna w opiniach ludzi trzeciego wieku. In: A. Michalski (Ed.), Wokół teoretycznych podstaw kształcenia muzycznego (pp. 211-226). Gdańsk: Wydawnictwo Athenae Gedanenses.

Drozdowski, R. (2014). Relacje. In: R. Drozdowski, B. Fatyga, M. Filiciak, M. Krajewski, \& T. Szlendak, Praktyki kulturalne Polaków (pp. 300-336). Toruń: Wydawnictwo Naukowe Uniwersytetu Mikołaja Kopernika.

Filiciak, M., Danielewicz, M., Halawa, M., Mazurek, P., \& Nowotny, A. (2010). Młodzi i media. Nowe media a uczestnictwo w kulturze. Raport Centrum Badań nad Kulturq Popularnq SWPS. Warszawa: Szkoła Wyższa Psychologii Społecznej. 
Grad, J. (1997). Badania uczestnictwa w kulturze artystycznej w polskiej socjologii kultury. Analiza metodologiczno-teoretyczna. Poznań: Wydawnictwo Naukowe.

Janicka-Olejnik, E. (2016). Uczestnictwo Polaków w kulturze w świetle aktualnych raportów. Studia Bas, 2, pp. 57-75.

Koryś, I., Kopeć, J., Zasacka, Z., \& Chymkowski, R. (2017). Stan czytelnictwa w Polsce w 2016 roku. Raport. Retrieved from: http://www.nck.pl/badania/raporty/raport-stan-czytelnictwa-w-polsce-w-2016-roku (accessed: 18.02.2018).

Krajewski, M. (2014). Uczestnictwo w kulturze. In: R. Drozdowski, B. Fatyga, M. Filiciak, M. Krajewski, \& T. Szlendak, Praktyki kulturalne Polaków (pp. 12-19). Toruń: Wydawnictwo Naukowe Uniwersytetu Mikołaja Kopernika.

Landsberg, P., Poprawski, M., Kieliszewski, P., Mękarski, M., Gojlik, A., Kuchta, J., Brodniewicz, M., \& Sójka, J. (2012). Po co seniorom kultura? Badania kulturalnych aktywności osób starszych. Raport. Retrieved from: http://www.nck.pl/upload/attachments/302557/ po_co_seniorom_kultura_raport.pdf (accessed: 24.02.2018).

LeBlanc, A. (1991), Some Unanswered Questions in Music Preference Research. Contribution to Music Education, 18, pp. 66-73.

LeBlanc, A., Sims, W.L., Siivola, C., \& Obert, M. (1996). Music Style Preferences of Different Age Listeners. Journal of Research in Music Education, 44 (1), pp. 49-59.

O’Hagan, J. (2016). European Statistics on Cultural Participation and Their International Comparability. International Journal of Cultural Policy, 22 (2), pp. 291-303. DOI: 10.10 80/10286632.2014.973870.

Pałosz, P. (2009). Przegląd badań nad uwarunkowaniami preferencji muzycznych. Przegląd Psychologiczny, 52 (2), pp. 151-179.

Radkowski, S., Wawrzyniak, K., Kalinowski, P., \& Łysoń, P. (2016). Uczestnictwo ludności w kulturze w 2014 r. Warszawa: Główny Urząd Statystyczny.

Straś-Romanowska, M. (opracowanie) (2009). Późna dorosłość. Wiek starzenia się. In: B. Harwas-Napierała, \& J. Trempała (Eds.), Psychologia rozwoju człowieka. Charakterystyka okresów życia człowieka (pp. 263-287). Warszawa: Wydawnictwo Naukowe PWN.

Szlendak, T. (2014a). Uzasadnienia: “tradycyjna” i “nowa” aktywność kulturalna, grupowa i indywidualna. In: R. Drozdowski, B. Fatyga, M. Filiciak, M. Krajewski, \& T. Szlendak, Praktyki kulturalne Polaków (pp. 29-32). Toruń: Wydawnictwo Naukowe Uniwersytetu Mikołaja Kopernika.

Szlendak, T. (2014b). Formy aktywności kulturalnej. In: R. Drozdowski, B. Fatyga, M. Filiciak, M. Krajewski, \& T. Szlendak, Praktyki kulturalne Polaków (pp. 141-210). Toruń: Wydawnictwo Naukowe Uniwersytetu Mikołaja Kopernika.

Szlendak, T., \& Olechnicki, K. (2014). Megaceromoniały i subświaty. O potransformacyjnych przemianach uczestnictwa Polaków w kulturze. Ruch Prawniczy, Ekonomiczny i Socjologiczny, 76(2), pp. 293-308. DOI: 10.14746/rpeis.2014.76.2.21.

Tomka, G. (2013). Reconceptualizing Cultural Participation in Europe: Grey Literature Review. Cultural Trends, 22 (3/4), pp. 259-264. DOI: 10.1080/09548963.2013.819657. 